\title{
Participation of prolactin receptors and phosphatidylinositol 3-kinase and MAP kinase pathways in the increase in pancreatic islet mass and sensitivity to glucose during pregnancy
}

\author{
Maria E C Amaral, Daniel A Cunha, Gabriel F Anhế ${ }^{1}$, \\ Mirian Ueno ${ }^{2}$, Everardo M Carneiro, Lício A Velloso², \\ Silvana Bordin ${ }^{1}$ and Antonio C Boschero \\ Departamento de Fisiologia e Biofísica, Instituto de Biologia, Faculdade de Ciências Médicas, Universidade Estadual de Campinas (UNICAMP), \\ Campinas, SP, Brazil \\ ${ }^{1}$ Departamento de Fisiologia e Biofísica, Instituto de Ciências Biomédicas, Universidade de São Paulo, São Paulo, SP, Brazil \\ ${ }^{2}$ Departamento de Clínica Médica, Faculdade de Ciências Médicas, Universidade Estadual de Campinas (UNICAMP), Campinas, SP, Brazil \\ (Requests for offprints should be addressed to A C Boschero; Email: boschero@unicamp.br)
}

\begin{abstract}
Prolactin (PRL) exerts its biological effects mainly by activating the Janus kinase/signal transducer and activator of transcription 5 (JAK/STAT5) signaling pathway. We have recently demonstrated that PRL also stimulates the insulin receptor substrates/phosphatidylinositol 3-kinase (IRSs/PI3K) and SH2-plekstrin homology domain (SHC)/ERK pathways in islets of neonatal rats. In the present study, we investigated the involvement of the PI3K and MAP kinase (MAPK) cascades in islet development and growth in pregnant rats. The protein expression of AKT1, p70 ${ }^{\mathrm{S} 6 \mathrm{~K}}$ and SHC was higher in islets from pregnant compared with control rats. Higher basal levels of tyrosine phosphorylation were found in classic transducers of insulin cell signaling (IRS1, IRS2 and SHC). Increased levels of threonine/tyrosine phosphorylation of ERK1/2 and serine phosphorylation of AKT and $\mathrm{p} 70^{\mathrm{S} 6 \mathrm{~K}}$ were also
\end{abstract}

detected. To assess the participation of PRL in these phenomena, pregnant and control rats were treated with an antisense oligonucleotide to reduce the expression of the PRL receptor (PRLR). Phosphorylation of AKT was reduced in islets from pregnant and control rats, whereas $\mathrm{p} 70^{\mathrm{S} 6 \mathrm{~K}}$ protein levels were reduced only in islets from treated pregnant rats. Finally, glucose-induced insulin secretion was reduced in islets from pregnant but not from control rats treated with the PRLR antisense oligonucleotide. In conclusion, downstream proteins of the PI3K (AKT and $\mathrm{p} 70^{\mathrm{S} 6 \mathrm{~K}}$ ) and MAPK (SHC and ERK1/2) cascades are regulated by PRL signaling in islets from pregnant rats. These findings indicate that these pathways participate in the increase in islet mass and the sensitivity to glucose during pregnancy.

Journal of Endocrinology (2004) 183, 469-476

\section{Introduction}

The growth and differentiation of the endocrine pancreas during the perinatal period and pregnancy are controlled by many factors, including a variety of hormonal, chemical and neural signals to the islets. Of these, placental lactogen $(\mathrm{PL})$, growth hormone $(\mathrm{GH})$ and prolactin $(\mathrm{PRL})$ play an important role (Brelje et al. 1993, Nielsen et al. 1999). PRL enhances insulin secretion, and this is reflected by a shift to the left in the glucose dose-response curves in isolated islets exposed to the hormone. PRL also decreases the glucose threshold and increases the gap-junctional coupling among $\beta$-cells (Parsons et al. 1992, CollaresBuzato et al. 2001). During pregnancy, the total islet mass increases, mainly through the proliferation of existing cells and by a reduction in cell death (Scaglia et al. 1997, Bonner-Weir 2001). In the rat, $\beta$-cell mass increases 50\% during pregnancy. However, during the first 10 days postpartum, this increased $\beta$-cell mass involutes through a reduction in $\beta$-cell volume and proliferation and an increase in $\beta$-cell apoptosis (Scaglia et al. 1995, Sorenson \& Brelje 1997). The over-expression of PL in pancreatic $\beta$-cells in vitro or in transgenic mice increases $\beta$-cell mass and insulin production (Fleenor et al. 2000, Vasavada et al. 2000). In contrast, the pancreatic islets of PRL receptor (PRLR)-deficient mice have a lower density, size and mass, as well as lower insulin mRNA levels and content (Freemark et al. 2002).

PRL exerts its biological effects mainly by activating the Janus kinase 2/signal transducer and activator of transcription 5 (JAK2/STAT5) pathway (Ihle et al. 1998, Galsgaard et al. 1999, Levy \& Darnell 2002), but can also stimulate insulin receptor substrate (IRS) $1 / 2$, phosphatidylinositol 3-kinase (PI3K) and MAP kinase (MAPK) in different cell 
lines (Rao et al. 1995, Yamauchi et al. 1998) and in cultured neonatal rat islets (Amaral et al. 2003). In addition, PRL enhances the expression of several genes related to growth and differentiation but reduces others involved in apoptosis (Bordin et al. 2004).

In the present study, we show that in islets from pregnant rats there is an increase in the expression and/or phosphorylation of several proteins involved in the PI3K and MAPK pathways. The treatment of pregnant rats with PRLR antisense oligonucleotide reduced the protein expression of PRLR, and this was accompanied by a reduction in $\mathrm{AKT}$ phosphorylation and $\mathrm{p} 70^{\mathrm{S} 6 \mathrm{~K}}$ expression, as well as a reduction of glucose-induced insulin secretion by isolated islets. These results indicate that PRL, by activating downstream proteins of the PI3K (AKT and $\mathrm{p} 70^{\mathrm{S} 6 \mathrm{~K}}$ ) and MAPK (SH2-plekstrin homology domain (SHC) and ERK1/2) cascades, may have an important role in increasing the islet mass and sensitivity to glucose during pregnancy.

\section{Materials and Methods}

\section{Materials}

The apparatus for SDS-PAGE and immunoblotting was from Bio-Rad (Richmond, CA, USA). All the chemicals used in the experiments for immunoblotting were from Sigma (St Louis, MO, USA). Rat PRL was from Dr A F Parlow (Harbor University of California Los Angeles Medical Center, USA) and was kindly provided by the National Hormone and Pituitary Program of the National Institute of Diabetes and Digestive and Kidney Diseases (NIDDK). $\left[{ }^{125} \mathrm{I}\right]$ Protein A, $\left[{ }^{125} \mathrm{I}\right]$ insulin, enhanced chemiluminescence (ECL) kits and nitrocellulose membranes (Hybond N, 0.45 $\mu \mathrm{m}$ ) were from Amersham (UK), and protein A Sepharose $6 \mathrm{MB}$ was from Pharmacia (Uppsala, Sweden). Anti-phosphotyrosine (mouse monoclonal, sc 508), anti-IRS1 (rabbit polyclonal, sc 559), anti-IRS2 (goat polyclonal, sc 1556), anti-SHC (rabbit polyclonal, sc 288), anti-phospho[Ser $\left.{ }^{473}\right]$ AKT (rabbit polyclonal, sc 7985), anti-AKT1 (mouse polyclonal sc 5298), antiphospho p70 $70^{\mathrm{S} 6 \mathrm{~K}}$ (rabbit polyclonal, sc 8416), anti-ERK1 (rabbit polyclonal, sc 94), anti-ERK2 (rabbit polyclonal, sc 154), anti- $\alpha$-tubulin (mouse monoclonal, sc 5286), and anti-p $70^{\mathrm{S} 6 \mathrm{~K}}$ (mouse monoclonal, sc 8418) antibodies were from Santa Cruz Biotechnology, Inc. (Santa Cruz, CA, USA); anti-PI3K p85 (rabbit polyclonal, 06-195) was from UBI (Lake Placid, NY, USA), anti-ERK1/2 (p44/42 MAPK mouse monoclonal, E10) was from Biolabs Inc. (Beverly, MA, USA) and anti-PRLR (mouse IgG1 clone U5) was from Affinity Bioreagents (Golden, CO, USA).

\section{Islet isolation}

Islets were isolated from six female Wistar rats (pregnant or not) by collagenase digestion of pancreata followed by separation from the pancreatic debris by centrifugation on Ficoll gradients. All the experimental protocols involving the use of animals were approved by the institutional (UNICAMP) Committee for Ethics in Animal Experimentation.

\section{Phosphorthioate-modified oligonucleotides}

Phosphorthioate-modified oligonucleotides were designed based on the Genbank accession no. M74152 for the Rattus norvegicus PRLR sequence and consisted of sense (5' AAC ATG CCA TCT GCA C $3^{\prime}$ ) and antisense (5' GTG CAG ATG GCA TGT T 3') oligonucleotides that were produced by Invitrogen (Carlsbad, CA, USA). These sequences were selected among three unrelated pairs of oligonucleotides on the basis of their ability to block PRLR protein expression as evaluated by immunoblots of total protein extracts of isolated pancreatic islets using anti-PRLR antibody. The sense and antisense oligonucleotides were diluted to a final concentration of $0.01 \mathrm{nmol} / \mu \mathrm{l}$ and $0.025 \mathrm{nmol} / \mu \mathrm{l}$ respectively, in dilution buffer containing $10 \mathrm{mM}$ Tris- $\mathrm{HCl}$ and $1 \mathrm{mM}$ EDTA. The rats were injected (i.p.) with 300 or $120 \mu$ of the solution containing sense or antisense oligonucleotides respectively, on the 16th, 17th, and 18th days of pregnancy (Bertelli et al. 2003).

\section{Tissue extracts and immunoblotting}

After incubation, the islets were homogenized in $200 \mu \mathrm{l}$ solubilization buffer (10\% Triton X-100, $100 \mathrm{mM}$ Tris $\mathrm{pH}$ 7.4, $10 \mathrm{mM}$ sodium pyrophosphate, $100 \mathrm{mM}$ sodium fluoride, $10 \mathrm{mM}$ EDTA, $10 \mathrm{mM}$ sodium vanadate, and $2 \mathrm{mM}$ PMSF) for $30 \mathrm{~s}$ using a Polytron PT $1200 \mathrm{C}$ homogenizer (Brinkmann Instruments, Westbury, NY, USA). The tissue extracts were centrifuged at 12000 r.p.m. at $4{ }^{\circ} \mathrm{C}$ for $20 \mathrm{~min}$ and the supernatant was used for protein quantification and for immunoprecipitation. The immuno precipitations were carried out by incubating aliquots of extracts with $15 \mu \mathrm{l}$ of anti-IRS1/2 or anti-SHC antibodies at $4{ }^{\circ} \mathrm{C}$ overnight. The immune complexes were then precipitated with protein A-Sepharose $6 \mathrm{MB}$ for $2 \mathrm{~h}$. The pellets were washed three times in buffer containing $100 \mathrm{mM}$ Tris, $2 \mathrm{mM}$ sodium vanadate, $1 \mathrm{mM}$ EDTA and $0.5 \%$ Triton X-100, resuspended in $18 \mu \mathrm{l}$ Laemmli sample buffer and boiled for 5 min prior to loading onto polyacrylamide gels ( $8 \%$ for anti-IRS1/2, and $15 \%$ for anti-SHC). Aliquots of total extracts containing $100 \mu \mathrm{g}$ protein for islets and uterus were run on $12 \%$ polyacrylamide gels containing SDS. Following electrophoresis, the proteins were transferred to nitrocellulose membranes for $2 \mathrm{~h}$ at $120 \mathrm{~V}$. Non-specific protein binding to nitrocellulose was reduced by preincubating the filter in blocking buffer (BSA 5\%, $10 \mathrm{mM}$ Tris, $150 \mathrm{mM} \mathrm{NaCl}$, and $0.02 \%$ Tween 20 ) for $2 \mathrm{~h}$ at $22^{\circ} \mathrm{C}$. The nitrocellulose membranes were then incubated for $2 \mathrm{~h}$ at $22^{\circ} \mathrm{C}$ with 
antiphosphotyrosine antibody, or anti-PI3K diluted in blocking buffer (BSA 3\%), and washed for $30 \mathrm{~min}$ in blocking buffer without BSA. The blots were then incubated with $2 \mu \mathrm{Ci}\left[{ }^{125} \mathrm{I}\right]$ protein $\mathrm{A}(30 \mu \mathrm{Ci} / \mu \mathrm{g})$ in $10 \mathrm{ml}$ blocking buffer for $1 \mathrm{~h}$ at $22^{\circ} \mathrm{C}$ and washed again as described above for $2 \mathrm{~h}$. $\left[{ }^{125} \mathrm{I}\right]$ Protein $\mathrm{A}$ bound to the antibodies was detected by autoradiography using preflashed Kodak film at $-80{ }^{\circ} \mathrm{C}$ for $24-60 \mathrm{~h}$. When detection by chemiluminescence was used, the membranes were incubated with a peroxidase-conjugated secondary antibody for $1 \mathrm{~h}$ at $22^{\circ} \mathrm{C}$. Band intensities were documented by digital scanning followed by quantification using Scion Image analysis software. When required, $\alpha$-tubulin was probed in the same membrane to ensure that equal amounts of protein had been loaded onto the gel.

\section{Insulin secretion}

Groups of five islets were initially incubated for $45 \mathrm{~min}$ at $37^{\circ} \mathrm{C}$ in Krebs-bicarbonate buffer containing $5.6 \mathrm{mM}$ glucose and equilibrated with $95 \% \mathrm{O}_{2} / 5 \% \mathrm{CO}_{2}, \mathrm{pH} 7 \cdot 4$. The solution was then replaced with fresh Krebsbicarbonate buffer and the islets were incubated for a further $1 \mathrm{~h}$ with medium containing 2.8 or $16.7 \mathrm{mM}$ glucose. The incubation medium contained (in $\mathrm{mM}$ ): $\mathrm{NaCl} 115, \mathrm{KCl} 5, \mathrm{NaHCO}_{3} 24, \mathrm{CaCl}_{2} 2 \cdot 56, \mathrm{MgCl}_{2} 1$, and BSA $0 \cdot 3 \%(\mathrm{w} / \mathrm{v})$. The cumulative insulin release during $1 \mathrm{~h}$ was quantified by radioimmunoassay using rat insulin as the standard.

\section{Statistical analysis}

The results were expressed as the mean \pm S.E.M. of the number of experiments $(n)$ indicated. The results were compared using ANOVA followed by the Tukey-Kramer test, with a value of $P<0.05$ indicating significance.

\section{Results}

Protein expression, phosphorylation of IRS1 and IRS2 and their association with the $p 85$ subunit of PI3K in pancreatic islets

The protein levels of IRS1 and IRS2 in islets from pregnant rats were not different from control islets (Fig. 1A and $\mathrm{B}$, left panels). Immunoprecipitation of islet extracts with anti-IRS1 or anti-IRS2 followed by immunoblotting with anti-phosphotyrosine antibodies revealed an increase in IRS1 (3-fold, $P<0 \cdot 05)$ and IRS2 (2.5-fold, $P<0 \cdot 05)$ phosphorylation in pregnant rat islets compared with the controls (Fig. 1A and B, middle panels). The increase in the phosphorylation of IRS1 and IRS2 was accompanied by an increased association with PI3K in islets from pregnant compared with control rats $(2 \cdot 3$-fold for both,

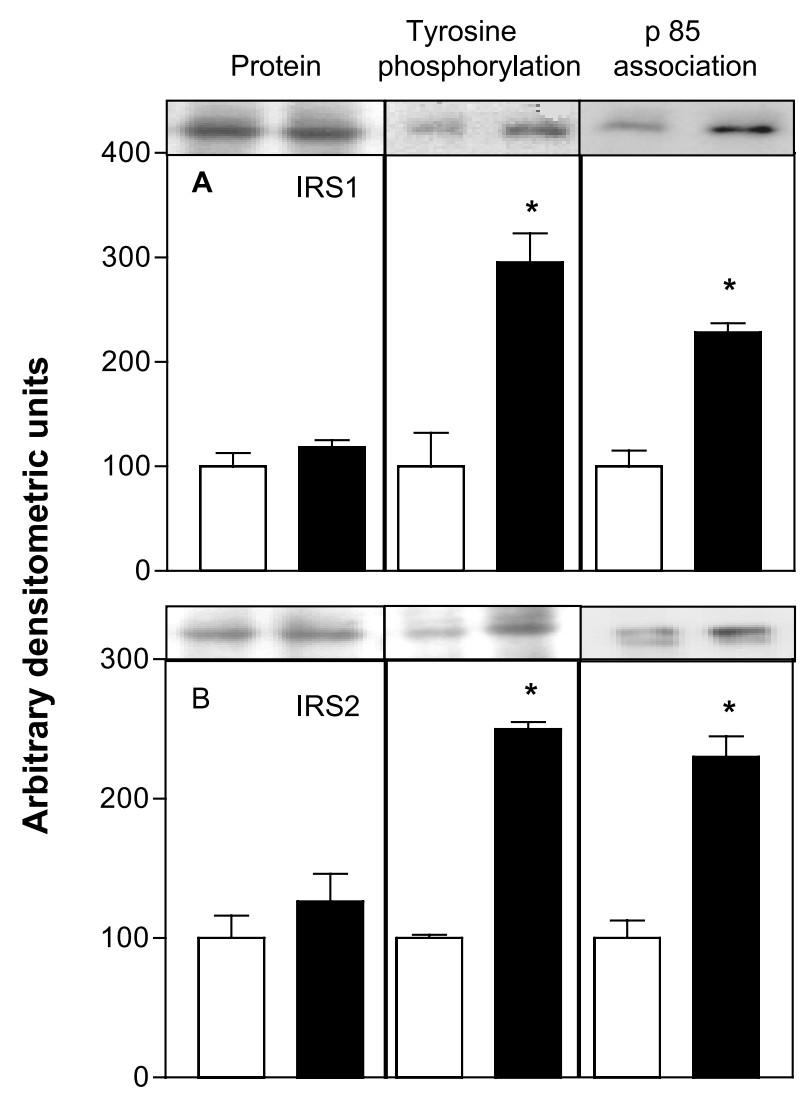

Figure 1 Tyrosine phosphorylation of IRS1 and IRS2 and their association with the $\mathrm{p} 85$ subunit of PI3K. Islet extracts were immunoprecipitated with anti-IRS1 (A) and anti-IRS2 (B) antibodies and immunoblotted with anti-phosphotyrosine antibody. The nitrocellulose membranes were subsequently stripped and probed with anti-p85 antibody. The bars represent the relative protein levels (left panels), phosphorylation of IRS1/2 (middle panels) and the association with p85 (right panels) as determined by optical densitometry, and are the means \pm S.E.M. of four experiments. ${ }^{*} P<0.05$ compared with the controls. Open and closed bars represent islets from control and pregnant rats respectively.

$P<0 \cdot 05)$, as determined by reprobing the membranes with antibody against the regulatory p 85 subunit of PI3K (Fig. 1A and B, right panels).

Protein expression and phosphorylation of $A K T$ and $p 70^{S 6 K}$ in pancreatic islets

To investigate the participation of downstream proteins of the PI3K cascade in cellular signaling in islets, groups of 300 islets were lysed, separated by SDS-PAGE and blotted with anti-AKT1 and anti-p $70^{\mathrm{S} 6 \mathrm{~K}}$ antibodies for protein and anti-phospho[Ser $\left.{ }^{473}\right] \mathrm{AKT}$ and anti-phospho $\mathrm{p} 70^{\mathrm{S} 6 \mathrm{~K}}$ antibodies for phosphorylation analysis. The protein levels of AKT1 and $\mathrm{p} 70^{\mathrm{S} 6 \mathrm{~K}}$ in islets from pregnant rats were higher than in the controls (Fig. 2A, C) (2- and 1.6fold respectively, $P<0 \cdot 05)$. The phosphorylation of AKT 


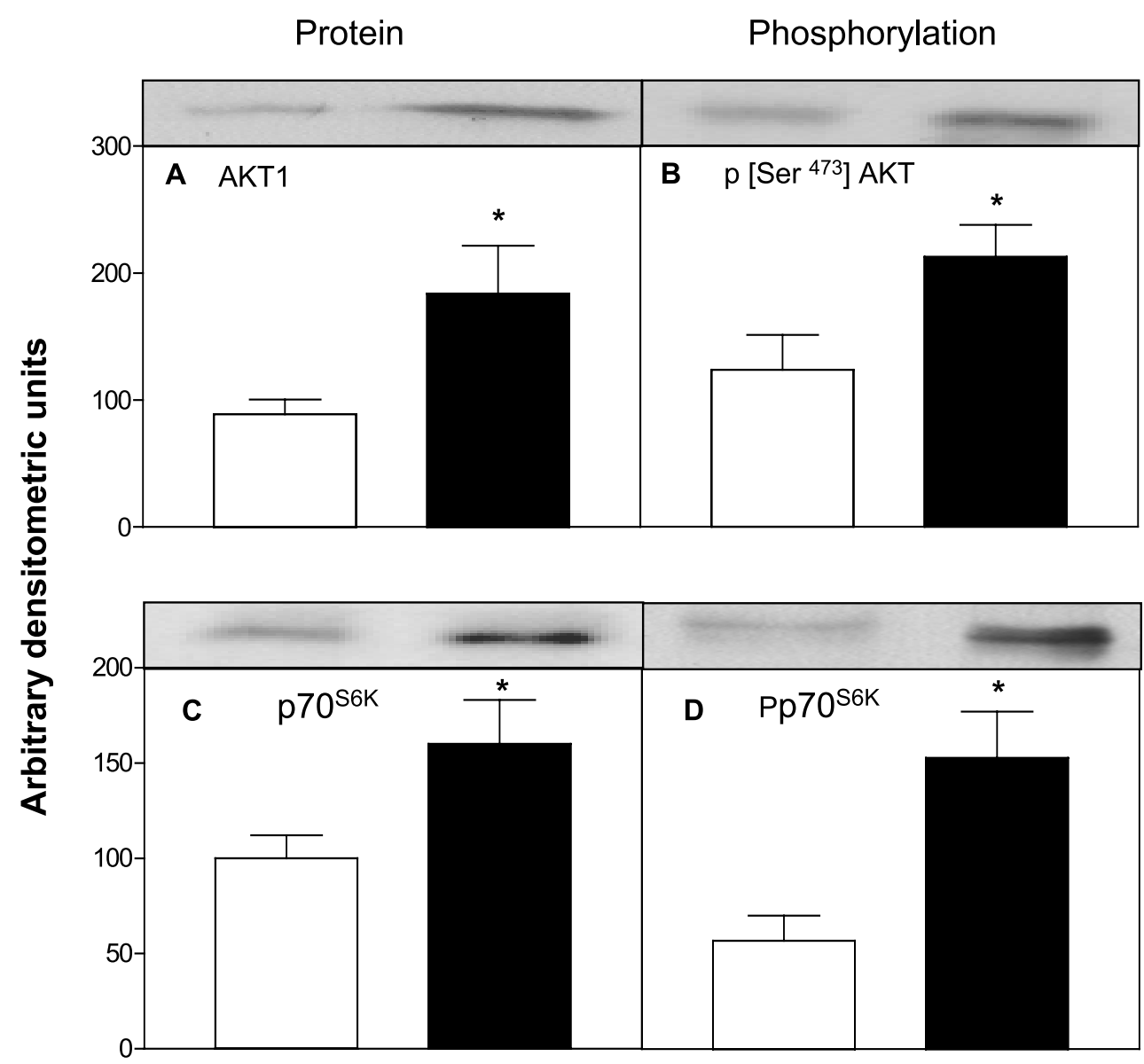

Figure 2 Protein expression and phosphorylation of $\mathrm{AKT}$ and $\mathrm{p} 70^{\mathrm{S} 6 \mathrm{~K}}$ in pancreatic islets. Islet extracts were immunoblotted with anti-AKT1 (A) and anti-p70 $70^{\mathrm{S} 6 \mathrm{~K}}$ (C) antibodies and anti-phospho[Ser $\left.{ }^{473}\right] \mathrm{AKT}(\mathrm{B})$ and anti-phospho $\mathrm{p} 70^{\mathrm{S} 6 \mathrm{~K}}$ (D) antibodies. The bars represent the relative protein expression and phosphorylation of AKT and $\mathrm{p} 70^{\mathrm{S6K}}$ as determined by optical densitometry, and are the means \pm S.E.M. of four experiments. ${ }^{*} P<0.05$ compared with the controls. Open and closed bars represent islets from control and pregnant rats respectively.

(Fig. 2B) and $\mathrm{p} 70^{\mathrm{S} 6 \mathrm{~K}}$ (Fig. 2D) was also significantly higher in islets of pregnant compared with control rats $(1 \cdot 8$ - and $2 \cdot 7$-fold respectively, $P<0 \cdot 05)$.

Protein expression and phosphorylation of SHC and ERK1/2 in pancreatic islets

To investigate the participation of SHC and the MAPK cascade in cellular signaling, groups of 300 islets were lysed, separated by SDS-PAGE and blotted with anti-SHC and anti-ERK1/2 antibodies, and anti-phospho-ERK1/2 antibody. The islet extracts were also immunoprecipitated with anti-SHC antibody followed by SDS-PAGE and blotting with anti-phosphotyrosine antibody. The protein levels $(2 \cdot 3$-fold, $P<0 \cdot 05)$ and phosphorylation $(3 \cdot 3$-fold, $P<0.05)$ of SHC were significantly higher in islets from pregnant rats compared with control islets (Fig. 3A, B).
The protein levels of ERK1/2 were similar in islets from pregnant and control rats (not significant) whereas tyrosine/ threonine phosphorylation was significantly higher in islets from pregnant rats $(2 \cdot 8$-fold, $P<0 \cdot 05)$ (Fig. 3C, D).

Effect of treatment with PRLR sense and antisense oligonucleotides on protein expression, phosphorylation and insulin secretion in pancreatic islets

To test the involvement of PRLR in the increase in islet mass and the participation of the PI3K cascade in this process, control and pregnant rats were treated with PRLR sense and antisense oligonucleotide for three consecutive days. The treatment with antisense, but not sense, oligonucleotide significantly reduced PRLR protein expression in the uterus (Fig. 4A) and islets (Fig. 4B) $(P<0.05$ for both). The PRLR sense and antisense 


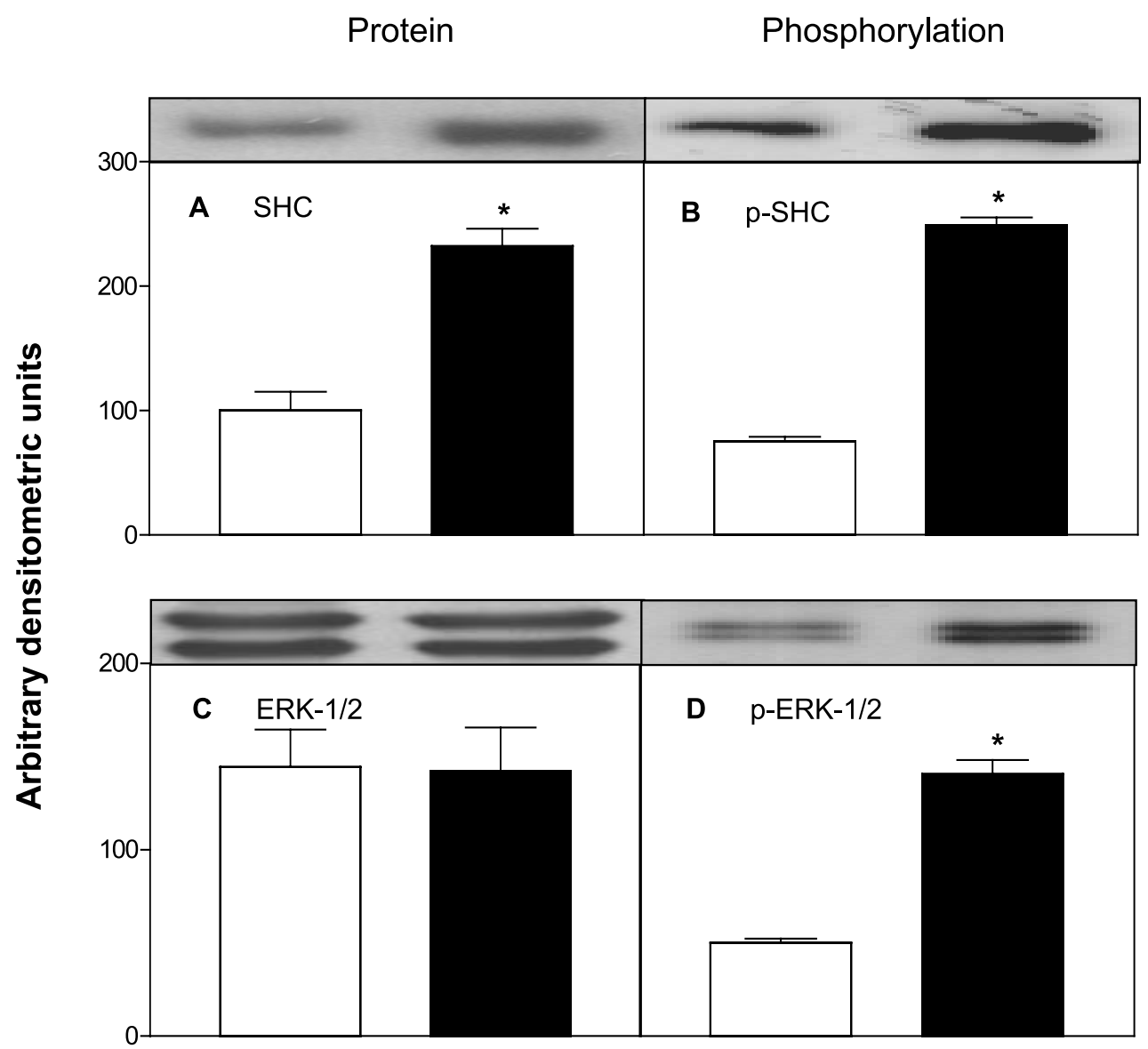

Figure 3 Protein expression and phosphorylation of SHC and ERK in pancreatic islets. Islet extracts were immunoblotted with anti-SHC (A). For SHC tyrosine phosphorylation, islet extracts were immunoprecipitated with anti-SHC antibody and immunoblotted with anti-phosphotyrosine antibody (B). Islet extracts were also immunoblotted with anti-ERK (C) and anti-phospho-ERK1/2 (D) antibodies. The bars represent the relative protein levels and the phosphorylation of SHC and ERK as determined by optical densitometry, and are the mean \pm S.E.M. of four experiments. ${ }^{*} P<0 \cdot 05$ compared with the controls. Open and closed bars represent islets from control and pregnant rats respectively.

oligonucleotides did not alter the expression of $\alpha$-tubulin used as an internal control (Fig. 4A). In addition, treatment with the antisense significantly reduced the serine phosphorylation of AKT (Fig. 5A) in islets from both pregnant and control rats $(P<0.05$ for both). The PRLR antisense oligonucleotide also reduced the protein expression of p $70^{\mathrm{S} 6 \mathrm{~K}}$ in islets from pregnant rats compared with similar islets treated with the sense oligonucleotide (Fig. 5B) $(P<0 \cdot 05)$. The treatment of control rats with sense or antisense oligonucleotides did not alter the insulin secretion by isolated islets incubated with basal $(2.8 \mathrm{mM})$ or stimulatory $(16.7 \mathrm{mM})$ concentrations of glucose (Fig. 6, left panels). However, treating pregnant rats with antisense oligonucleotide significantly reduced the insulin secretion stimulated by $16.7 \mathrm{mM}$ glucose compared with islets from pregnant rats treated with the PRLR sense oligonucleotide $(P<0 \cdot 05)$ (Fig. 6, right panels).

\section{Discussion}

The activation of JAK/STAT is the major pathway involved in most of the cellular responses induced by the interaction of $\mathrm{GH}$ and $\mathrm{PRL}$ with their respective receptors in different cell types, including pancreatic $\beta$-cells (BoleFeysot et al. 1998, Brelje et al. 2002). Signal transduction by GH and PRL also involves the tyrosine phosphorylation of IRS proteins with subsequent association/ activation of PI3K, as seen in different cell lines transfected with PRLR (Berlanga et al. 1997, Yamauchi et al. 1998). In rat $\mathrm{Nb} 2$ lymphoma cells (Erwin et al. 1995) and $\mathrm{CHO}$ cells expressing the wild-type PRLR (Goupille et al. 2000), PRL-induced activation of the MAPK cascade most likely occurs through the adapter protein complex SHC/GRB-2/SOS. These observations were recently extended to pancreatic neonatal islets maintained in culture 


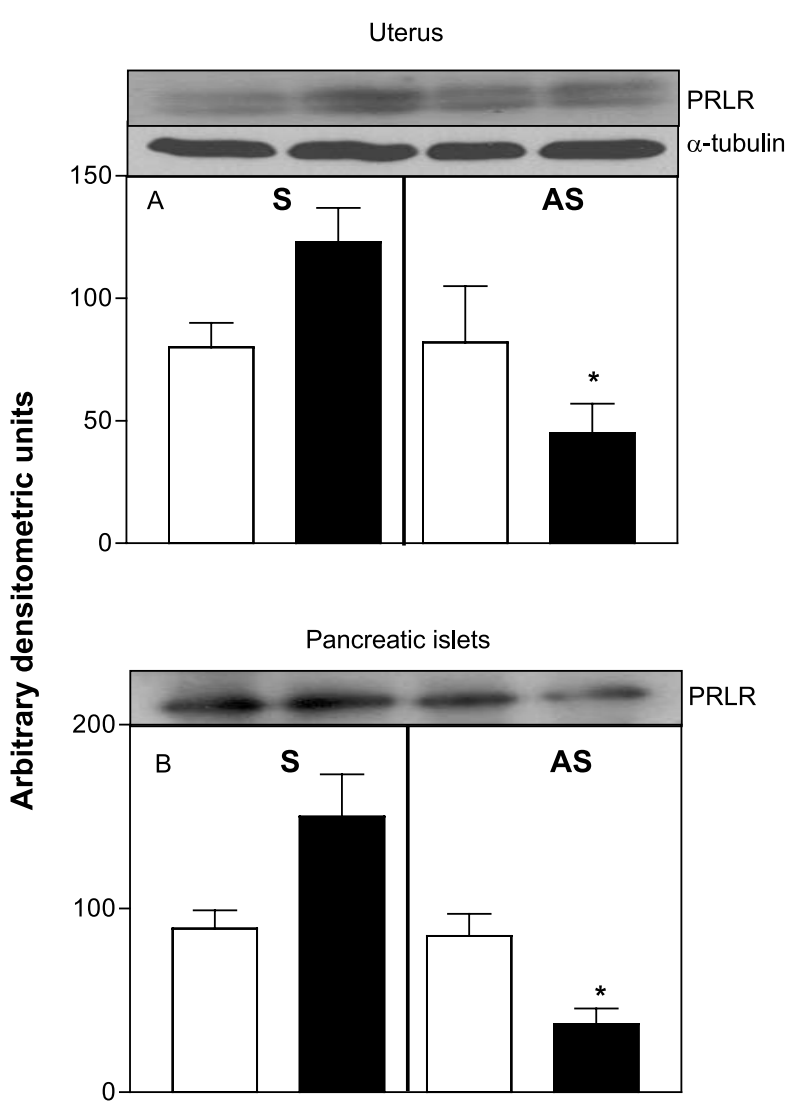

Figure 4 Expression of PRLR protein in uterus and islets from rats treated with PRLR sense (S) and antisense (AS) oligonucleotides. Total protein extracts of uterus (A) and islets (B) were immunoblotted with anti-PRLR antibody. The extracts of uterus were also immunoblotted with anti- $\alpha$-tubulin. The bars represent the protein levels as determined by optical densitometry, and are the means \pm S.E.M. of four experiments. ${ }^{*} P<0.05$ compared with the controls. Open and closed bars represent islets from control and pregnant rats respectively.

in the presence of PRL or exposed to a rapid challenge with PRL (Amaral et al. 2003).

As shown in Fig. 1, the basal phosphorylation of IRS1/2 and their association with PI3K were significantly increased in islets from pregnant rats compared with the controls. The link between insulin signaling and secretion has been demonstrated in IRS1 knockout (KO) mice, which show marked insulin secretory defects in response to glucose and reduced insulin synthesis (Kulkarni et al. 1999), and in IRS2 KO mice, which primarily show a decrease in $\beta$-cell mass (Withers et al. 1998). More recently, the defective glucose sensing in IRS1 KO mice was found to be associated with impaired intracellular $\mathrm{Ca}^{2+}$ signaling (Kulkarni et al. 2004). Based on these observations, it is possible that the higher basal activity of the IRSs-PI3K cascades partly mediates $\beta$-cell growth and improves insulin secretion in pregnant rats.

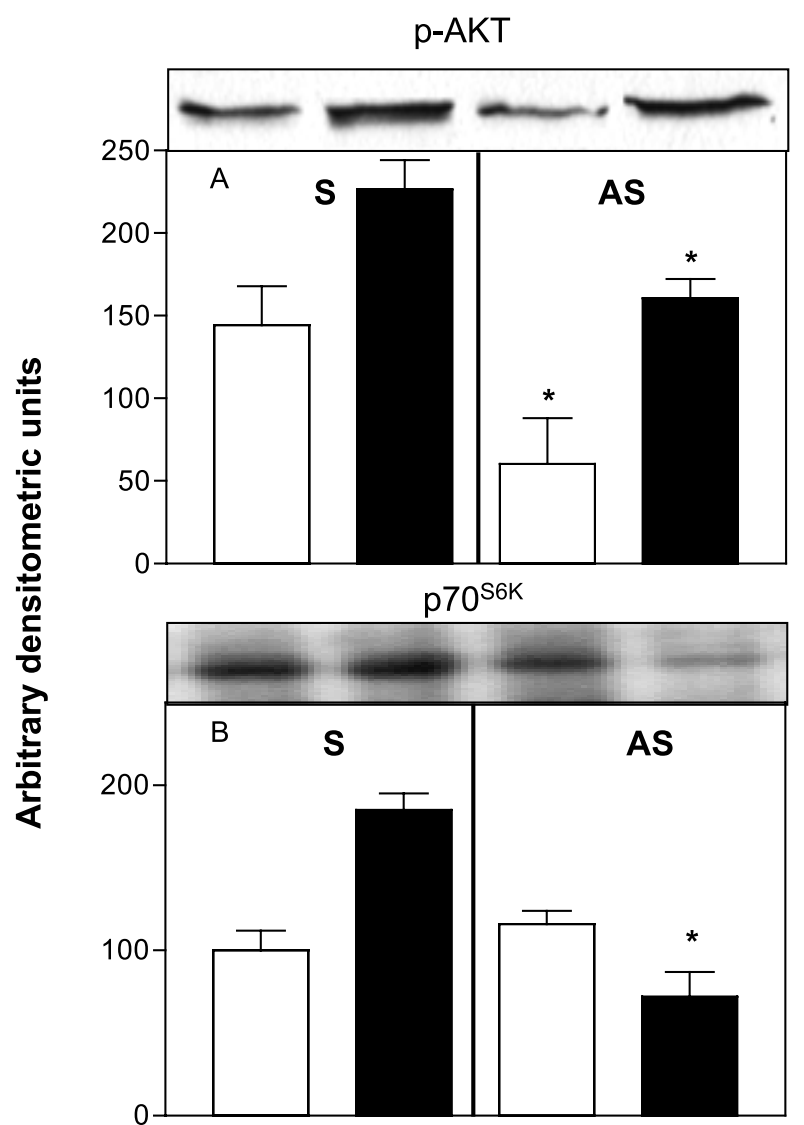

Figure 5 Phosphorylation of AKT and protein expression of $\mathrm{p} 70^{\mathrm{S} 6 \mathrm{~K}}$ in pancreatic islets from rats treated with PRLR sense $(S)$ and antisense (AS) oligonucleotides. Islet extracts from pregnant and control rats treated with PRLR sense and antisense

oligonucleotides were immunoblotted with anti-phospho-AKT (A) and anti-p $70^{\mathrm{S} 6 \mathrm{~K}}$ (B) antibodies. The bars represent the relative phosphorylation of AKT and protein expression of $\mathrm{p} 70^{\mathrm{S} 6 \mathrm{~K}}$ as determined by optical densitometry, and are the means \pm S.E.M. of four experiments. ${ }^{*} P<0.05$ compared with the corresponding controls ( $\mathrm{S}$ vs $\mathrm{AS}$ ). Open and closed bars represent islets from control and pregnant rats respectively.

Indeed, the increased IRSs-PI3K associations were accompanied by a significant increase in the protein expression and phosphorylation of AKT and $\mathrm{p} 70^{\mathrm{S} 6 \mathrm{~K}}$ (Fig. 2). The higher level of AKT1 $\mathrm{Ser}^{473}$ phosphorylation is an important step in the adaptations observed in pregnant rat islets. Transgenic mice expressing a constitutive active form of AKT1 in $\beta$-cells show a marked increase in $\beta$-cell mass that involves mainly enhanced $\beta$-cell survival and increased $\beta$-cell size (Tuttle et al. 2001). Ablation of $\mathrm{p} 70^{\mathrm{S} 6 \mathrm{~K}}$, an AKT substrate, reduces the sensitivity to glucose, the islet insulin content and cell size (Pende et al. 2000). Thus, our results clearly indicate the participation of PI3K signaling pathways in the alterations in islet cell physiology during pregnancy.

In several signaling pathways, the phosphorylation of members of the MAPK cascade activates several 


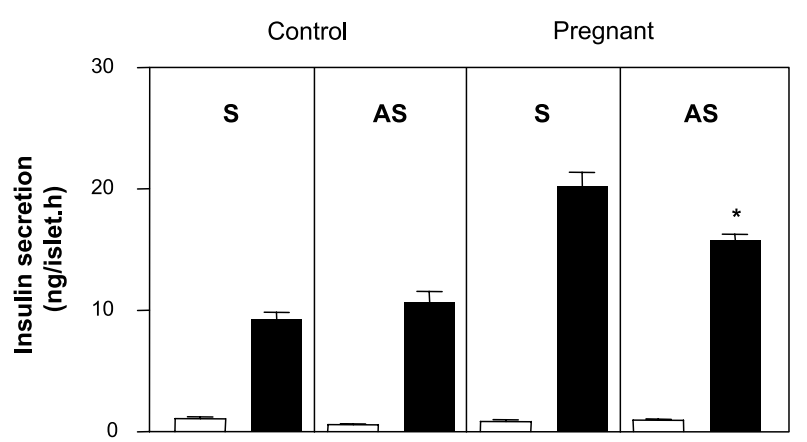

Figure 6 Glucose-induced insulin secretion in islets from rats treated with PRLR sense (S) and antisense (AS) oligonucleotides. Groups of five islets were initially incubated for $45 \mathrm{~min}$ at $37{ }^{\circ} \mathrm{C}$ in Krebs-bicarbonate buffer containing $5.6 \mathrm{mM}$ glucose and equilibrated with $95 \% \mathrm{O}_{2}-5 \% \mathrm{CO}_{2}, \mathrm{pH} 7 \cdot 4$. The solution was then replaced with fresh Krebs-bicarbonate buffer and the islets were incubated for a further $1 \mathrm{~h}$ with medium containing $2.8 \mathrm{mM}$ glucose (open bars) or $16.7 \mathrm{mM}$ glucose (closed bars). The bars represent the cumulative insulin secretion during $1 \mathrm{~h}$, and are the means \pm S.E.M. of 18 experiments. ${ }^{*} P<0 \cdot 05$ for antisense vs sense oligonucleotides in $16.7 \mathrm{mM}$ glucose in islets from pregnant rats.

transcriptional regulators to control cellular growth. Figure 3 shows that SHC and ERK were phosphorylated more in islets from pregnant rats than in those from control rats, thus indicating that the MAPK pathway is also involved in cellular functions such as growth and differentiation during pregnancy. This conclusion is consistent with the finding that PRL activates the PI3K and MAPK cascades in neonatal rat islets (Amaral et al. 2003). According to Friedrichsen et al. (2001), GH/PRL-induced $\beta$-cell proliferation is dependent on the JAK/STAT5 signaling pathway but not on the MAPK, PI3K and PKC pathways in isolated $\beta$-cells and the INS-1 cell line. Our results apparently contradict these data, although it is possible that the model used by these authors (isolated $\beta$-cells) may have slightly different signal transduction mechanisms than do intact islets (our model). The following findings (1) that the treatment of adult rat islets with PRL for $24 \mathrm{~h}$ enhanced the expression of ERK1/2, of the proliferation marker proliferating cell nuclear antigen (PCNA) and of several regulators of protein biosynthesis (Bordin et al. 2004), (2) that islets show an increase in cell proliferation and cell size during pregnancy, and (3) that the IRS2$\mathrm{PI} 3 \mathrm{~K}-\mathrm{AKT}-\mathrm{p} 70^{\mathrm{S} 6 \mathrm{~K}}$ axis participates in cell growth in other tissues (Accili et al. 2001) support the view that PI3K mediates cell growth in islets, whereas an unknown signal downstream of AKT promotes cell proliferation during pregnancy.

Since the PRL concentrations and the number of PRLR in pancreatic $\beta$-cells are increased in late pregnancy (Sorenson \& Brelje 1997), we treated pregnant and control rats with PRLR sense and antisense oligonucleotides to evaluate the participation of the PRLR during this period. As shown in Fig. 4, the expression of PRLR protein in uterus and islets from pregnant rats was significantly reduced by treatment with the antisense but not the sense oligonucleotide. In addition, the insulin secretion induced by $16.7 \mathrm{mM}$ glucose in islets from pregnant rats treated with the antisense oligonucleotide was significantly reduced compared with that seen with the sense oligonucleotide. In agreement with our findings, the overexpression of placental lactogens in insulin-producing cells increases the $\beta$-cell mass and insulin production (Fleenor et al. 2000, Vasavada et al. 2000), whereas in PRLRdeficient mice there is islet and $\beta$-cell hypoplasia accompanied by a reduction in insulin mRNA levels and mild glucose intolerance (Freemark et al. 2002). Thus, our results indicate that the PRLR mediates the effects of placental lactogens and PRL on $\beta$-cell maturation, development and function. The reduction in AKT phosphorylation and $\mathrm{p} 70^{\mathrm{S} 6 \mathrm{~K}}$ protein expression seen in islets from PRLR antisense-treated pregnant rats (Fig. 5) strongly indicated the participation of PI3K in this process. However, we have no conclusive explanation as to why the PRLR antisense oligonucleotide did not reduce PRLR expression in the uterus and islets of control rats. Since the role of PRLR in islets during pregnancy is far more important than in the non-pregnant state, it is possible that in control rats the blockade induced by the antisense oligonucleotide was not sufficient to provoke a significant difference in PRLR expression.

The results of this study show that, in addition to the participation of the well-known JAK/STAT pathway, $\beta$-cell growth and differentiation in pregnant rats induced by PLs and PRL is mediated by the PRLR and involves the PI3K and MAPK cascades.

\section{Acknowledgements}

This work was partly supported by the Brazilian foundations FAPESP, CAPES and CNPQ/PRONEX. The authors thank L D Teixeira, H C Barbosa and L Janeri for technical assistance and Dr S Hyslop for editing the English.

\section{References}

Accili D 2001 A kinase in the life of the beta cell. Journal of Clinical Investigation 108 1575-1576.

Amaral MEC, Ueno M, Carvalheira JB, Carneiro EM, Velloso LA, Saad MJA \& Boschero AC 2003 Prolactin signal transduction in neonatal rat pancreatic islets and interaction with insulin signaling pathway. Hormone and Metabolic Research 35 282-289.

Berlanga JJ, Gualillo O, Buteau H, Applanat M, Kelly PA \& Edery M 1997 Prolactin activates tyrosyl phosphorylation of insulin receptor substrate 1 and phosphatidylinositol-3-OH kinase. Journal of Biological Chemistry 272 2050-2052.

Bertelli DF, Ueno M, Amaral MEC, Toyama MH, Carneiro EM, Marangoni S, Carvalho CRO, Saad MJA, Velloso LA \& Boschero AC 2003 Reversal of denervation-induced insulin resistance by SHIP2 protein synthesis blockade. American Journal of PhysiologyEndocrinology and Metabolism 284 E679-E687. 
Bole-Feysot C, Goffin V, Edery M, Binart N \& Kelly PA 1998 Prolactin (PRL) and its receptor: actions, signal transduction pathways and phenotypes observed in PRL receptor knockout mice. Endocrine Reviews 19 225-268.

Bonner-Weir S 2001 -Cell turnover, its assessment and implications. Diabetes 50 (Suppl 1) S20-S24.

Bordin S, Amaral MEC, Anhê GF, Delghingaro-Augusto V, Cunha DA, Nicoletti-Carvalho JE \& Boschero AC 2004

Prolactin-modulated gene expression profiles in pancreatic islets from adult female rats. Molecular and Cellular Endocrinology 200 41-50.

Brelje TC, Scharp DW, Lacy PE, Ogren L, Talamantes F, Robertson M, Friesen HG \& Sorenson RL 1993 Effect of homologous placental lactogens, prolactins, and growth hormones on islet B-cell division and insulin secretion in rat, mouse, and human islets: implication for placental lactogen regulation of islet function during pregnancy. Endocrinology 132 879-887.

Brelje TC, Svensson AM, Stout LE, Bhagroo NV \& Sorenson RL 2002 An immunohistochemical approach to monitor the prolactin-induced activation of the JAK2/STAT5 pathway in pancreatic islets of Langerhans. Journal of Histochemistry and Cytochemistry 50 365-383.

Collares-Buzato CB, Leite AR \& Boschero AC 2001 Modulation of gap and adherens junctional proteins in cultured neonatal pancreatic islets. Pancreas 23 177-185.

Erwin RA, Kirken RA, Malabarba MG, Farrar WL \& Rui H 1995 Prolactin activates Ras via signaling proteins SHC, growth factor receptor bound 2, and son of sevenless. Endocrinology 136 3512-3518.

Fleenor D, Petryk A, Driscoll P \& Freemark M 2000 Constitutive expression of placental lactogen in pancreatic beta cells: effects on cell morphology, growth, and gene expression. Pediatric Research $\mathbf{4 7}$ 136-142.

Freemark M, Avril I, Fleenor D, Driscoll P, Petro A, Opara E, Kendall W, Oden J, Bridges S, Binart N, Breant B \& Kelly PA 2002 Targeted deletion of the PRL receptor: effects on islet development, insulin production, and glucose tolerance. Endocrinology 143 1378-1385.

Friedrichsen BN, Galsgaard ED, Nielsen JH \& Moldrup A 2001 Growth hormone- and prolactin-induced proliferation of insulinoma cells, INS-1, depends on activation of STAT5 (signal transducer and activator of transcription 5). Molecular Endocrinology 15 136-148.

Galsgaard ED, Nielsen JH \& Moldrup A 1999 Regulation of prolactin receptor (PRLR) gene expression in insulin-producing cells. Prolactin and growth hormone activate one of the rat prlr gene promoters via STAT5a and STAT5b. Journal of Biological Chemistry 274 18686-18692.

Goupille O, Barnier J-V, Guibert B, Paly J \& Djiane J 2000 Effect of PRL on MAPK activation: negative regulatory role of the C-terminal part of the PRL receptor. Molecular and Cellular Endocrinology 159 133-146.

Ihle JN, Stravapodis D, Parganas E, Thierfelder W, Feng J, Wang D \& Teglund S 1998 The roles of Jaks and Stats in cytokine signaling. Cancer Journal of Scientific American 4 (Suppl 1) S84-S91.

Kulkarni RN, Winnay JN, Daniels M, Bruning JC, Flier SN, Hanahan D \& Kahn CR 1999 Altered function of insulin receptor substrate-1-deficient mouse islets and cultured beta-cell lines. Journal of Clinical Investigation 104 R69-R75.
Kulkarni RN, Roper MG, Dahlgren G, Shih DQ, Kauri LM, Peters JL, Stoffel M \& Kennedy RT 2004 Islet secretory defect in insulin receptor substrate 1 null mice is linked with reduced calcium signaling and expression of sarco(endo)plasmic reticulum $\mathrm{Ca}^{2+}$-ATPase (SERCA)-2b and -3. Diabetes 53 1517-1525.

Levy DE \& Darnell JE Jr 2002 Stats: transcriptional control and biological impact. Nature Reviews. Molecular Cell Biology 3 651-662.

Nielsen JH, Svensson C, Galsgaard ED, Moldrup A \& Billestrup N 1999 Beta cell proliferation and growth factors. Journal of Molecular Medicine 77 62-66.

Parsons JA, Brelje TC \& Sorenson RL 1992 Adaptation of islets of Langerhans to pregnancy: increased islet cell proliferation and insulin secretion correlates with the onset of placental lactogen secretion. Endocrinology 130 1459-1466.

Pende M, Kozma SC, Jaquet M, Oorschot V, Burcelin R, Le Marchand-Brustel Y, Klumperman J, Thorens B \& Thomas G 2000 Hypoinsulinaemia, glucose intolerance and diminished beta-cell size in S6K1-deficient mice. Nature 408 994-997.

Rao YP, Buckley DJ \& Buckley AR 1995 Rapid activation of mitogen-activated protein kinase and $\mathrm{p} 21$ ras by prolactin and interleukin 2 in rat $\mathrm{Nb} 2$ node lymphoma cells. Cell Growth and Differentiation 6 1235-1244.

Scaglia L, Smith FE \& Bonner-Weir S 1995 Apoptosis contributes to the involution of beta cell mass in the post partum rat pancreas. Endocrinology 136 5461-5468.

Scaglia L, Cahill CJ, Finegood DT \& Bonner-Weir S 1997 Apoptosis participates in the remodeling of the endocrine pancreas in the neonatal rat. Endocrinology 138 1736-1741.

Sorenson RL \& Brelje TC 1997 Adaptation of islets of Langerhans to pregnancy: beta-cell growth, enhanced insulin secretion and the role of lactogenic hormones. Hormone and Metabolic Research 29 301-307.

Tuttle RL, Gill NS, Pugh W, Lee JP, Koeberlein B, Furth EE, Polonsky KS, Naji A \& Birnbaum MJ 2001 Regulation of pancreatic beta-cell growth and survival by the serine/threonine protein kinase Akt1/PKBalpha. Nature Medicine 7 1133-1137.

Vasavada RC, Garcia-Ocaña A, Zawalich WS, Sorenson RL, Dann P, Syed M, Ogren L, Talamantes F \& Stewart AF 2000 Targeted expression of placental lactogen in the beta cells of transgenic mice results in beta cell proliferation, islet mass augmentation, and hypoglycemia. Journal of Biological Chemistry 275 15399-15406.

Withers DJ, Gutierrez JS, Towery H, Burks DJ, Ren JM, Previs S, Zhang Y, Bernal D, Pons S, Shulman GI, Bonner-Weir S \& White MF 1998 Disruption of IRS-2 causes type 2 diabetes in mice. Nature 391 900-904.

Yamauchi T, Kaburagi Y, Ueki K, Tsuji Y, Stark GR, Kerr IM, Tsushima T, Akanuma Y, Komuro I, Tobe K, Yasaki Y \& Kadowaki T 1998 Growth hormone and prolactin stimulate tyrosine phosphorylation of insulin receptor substrate-1, -2 , and -3 , their association with p 85 phosphatidylinositol 3-kinase (PI3-kinase), and concomitantly PI3-kinase activation via JAK2 kinase. Journal of Biological Chemistry 273 15719-15726.

Received 15 July 2004

Accepted 19 August 2004 